\title{
An Impact of the Euro Adoption on the International Trade of New EMU Members: the Lithuanian Case
}

\section{Gražina Startienè, Daiva Dumčiuvienè, Alina Stundžienė, Andrius Januškevičius}

\section{A B S T R A C T}

Objective: This article aims to assess the impact of the euro on the Lithuanian international trade by detecting the changes of the relevant economic indicators before and after the country's entry into the Eurozone.

Research Design \& Methods: The research is based on the gravity model of trade. The parameters of the model show elasticity of trade in respect of the determinants that are incorporated. The parameters of the model are estimated by the panel least square method.

Findings: The results obtained using the gravity model showed that the euro has significantly increased the Lithuanian intra-Eurozone trade, with an effect of 23$44 \%$. The size of effect depends on the model specification.

Implications \& Recommendations: The results can be used to discuss the positive impact of a common currency on the economics of a country. It is important for those EU members which still have not adopted the euro.

Contribution \& Value Added: Previous studies showed a different impact of the common currency on trade volumes, and the results depend on many factors, i.e. country, period, method and so on. This research supplements previous studies and reveals that the euro adoption has a positive impact on specifically Lithuanian trade volumes.

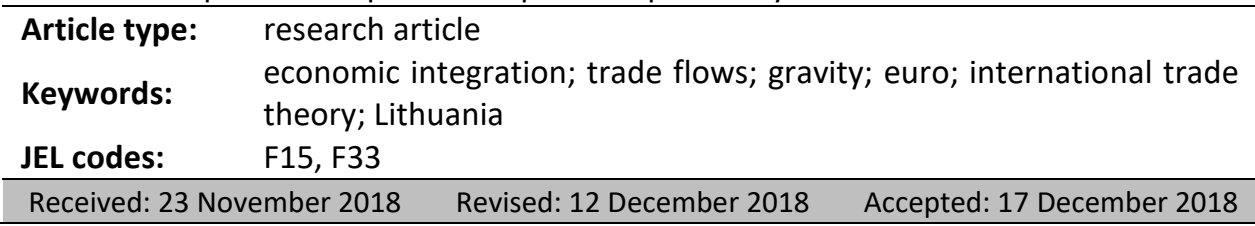

Suggested citation:

Startienė, G., Dumčiuvienė, D., Stundžienè, A., \& Januškevičius, A. (2019). An Impact of Euro Adoption on International Trade of New EMU Members: Lithuanian Case. Entrepreneurial Business and Economics Review, 7(1), 201-215. https://doi.org/10.15678/EBER.2019.070111 


\section{INTRODUCTION}

Although scientific literature is rich in research on the advantages and possible threats of monetary unions, the benefit provided by the common currency to the economies of different countries still remains a topical issue. Introduction of the common currency in Europe was an important step towards further integration and development of the economies of the EU member states. After the entry into the EU in 2004, Lithuania started the processes of integration in the common Economic and Monetary Union. The first attempt to introduce the euro in 2007 failed due to incompliance with one of the criteria of the convergence (in particular, inflation rate). Later on, the economic recession in Lithuania over the period of the global financial crisis delayed the plans of the common currency introduction. Nevertheless, Lithuania was able to introduce the common European currency on 1 January 2015 and became the nineteenth member of the Eurozone. As already mentioned, participation in a monetary union may have both positive and negative effects. Hence, it is purposeful to assess which economic changes are brought about by adoption of a common currency in each of the countries-participants.

The majority of the studies on the plausible impact of the euro on economies were carried out before the adoption of the common currency in particular countries, and only a small part of the studies focused on the assessment of the effects of the common currency after its introduction. The advantages and disadvantages of the euro adoption in different countries, as well as the impact of the euro on the main directions of national economies were analysed by Borowski et al. (2004), Bitans and Kaužens (2004), Šuster et al. (2006), Levišauskaite and Samys (2012) and others. In the case of Lithuania, a plausible impact of the euro on the Lithuanian economy was researched by Kuodis (2005), Kropas and Kropiene (2005), Davulis (2012), The Bank of Lithuania (2013) and others. The aim of the article is to assess the impact of the euro on the Lithuanian international trade by detecting changes of relevant economic indicators before and after the country's entry into the Eurozone.

The article is divided into the following sections. It starts with the theoretical aspects of pros and cons of the common currency, as well as the review of the previous research based on the impact of common currency on trade. Then, we present data and methods of our research. This research is based on the gravity model of trade which is estimated by the panel least squares method. Afterwards, the results of the estimated gravity model are presented and discussed. The conclusions are formulated in the last part of the article.

\section{LITERATURE REVIEW}

Scientific studies on the creation of monetary unions are mostly based on the optimum currency area theory (OCA) developed by Robert Mundell in 1961. Mundell (1961) argues that the adoption of a common currency is not economically beneficial to countries. He also defines OCA as a geographical area where a common currency could generate maximum economic benefits. The classical theory of OCA was also researched and further developed by McKinnon (1963), Kenen (1969), Ingram (1973), Corden (1972) and Ishiyama (1975). New attitudes towards the theory of OCA together with the results of the empirical research were presented by Tavlas (1993), Frankel and Rose (1998), Bayoumi and Eichen- 
green (1997), Alesina, Barro and Tenreyro (2002), Fidrmuc (2004), Horváth and Komárek (2002), Broz (2005), Mongelli (2008) and others.

The majority of scholars consider lower transaction costs as the main advantage of a common currency (Mundell, 1961; Broz, 2005; Mongelli, 2008; Silva \& Tenreyro, 2010; Svrtinov, Trajkovska, \& Temjanovski, 2014). Reduction of transaction costs is, in principle, linked to the growth of international trade among the member countries of a monetary union. According to Mongelli (2008) and Alesina, Barro and Tenreyro (2002), growing trade inside a monetary union determines lower transaction costs, which, in turn, strengthens the domestic market of goods and services, reduces the risk of investment, raises the scope of FDI and ensures better allocation of resources.

In addition to lower transaction costs, elimination of currency exchange uncertainty is considered to be another direct advantage of a common currency (Svrtinov, Trajkovska, \& Temjanovski, 2014). Growth of international trade is to the largest extent promoted by elimination of currency exchange uncertainty, which, in turn, determines reduction of transaction, currency exchange, insurance and other types of costs, diminishes the risk of trade transactions and decreases price volatility.

The empirical research proposes that the volumes of trade among the member countries, which initiated the creation of a monetary union or later joined it, tend to increase. Nevertheless, some empirical studies show that the rates of trade growth may vary, and the overall volumes of trade much depend on the period under analysis, the group of the countries involved and the statistical model employed for the research. Although a large number of studies are based on the gravity model of trade, employment of different variables may lead to different research results.

The first attempts to assess the impact of a common currency on international trade were made by Rose (2000). By employing the gravity model of trade, the author assessed the impact of exchange rate fluctuations and a monetary union on international trade in 186 countries. The results of the research revealed that the countries with a common currency trade with each other more actively (approximately three times) in comparison to the countries with different currencies. The studies carried out by other authors did not disclose any significant growth of trade among the countries with a common currency. The largest part of the studies was conducted based on the experience of the Eurozone member countries, i.e. the researchers attempted to assess the impact of the newly-adopted common currency on international trade of the member countries in 1999 (Table 1).

Referring to the study conducted by Rose (2000), Rose and Wincoop (2001) note that the establishment of the European Monetary Union (EMU) has reduced trade barriers and has led to an increase in EMU's trade volumes by over $50 \%$. By employing the data of the Eurozone domestic trade for 1965-2001, Bun and Klaassen (2002) estimated that the adoption of the euro contributed to an increase in the Eurozone's domestic trade by $3.9 \%$ over the first year, and by $9.6 \%$ over the third year; in the long run, the Eurozone's domestic trade was expected to increase by $40 \%$. Glick and Rose (2002) used a large annual panel data set covering 217 countries that participated in and left currency unions from 1948 through 1997 and estimated that 'a pair of countries that starts to use a common currency experiences a near doubling in bilateral trade' (Glick \& Rose, 2002, p. 1125).

On the other hand, the inclusion of the time trend in the model of the research revealed that the impact of the euro on the Eurozone's domestic trade constituted only $3 \%$ over the 
period under research (Bun \& Klaasen, 2007). A slightly higher impact was obtained by De Nardis and Vicarelli (2003) who noted that the adoption of the euro had a positive, although not very significant, impact on bilateral trade between the European countries. While analysing the data of 11 Eurozone member countries and 21 other countries for 1980-2000, the authors estimated that after the establishment of the EMU, an increase in its domestic trade composed $8.9 \%$ to $9.7 \%$, considering the relevant terms of the model. These results reveal a short-term impact of the common currency on the intra-EMU trade, meanwhile the longterm impact is more significant and amounts to $16.0-18.7 \%$.

Table 1. Summary of the Empirical Research on the Impact of a Common Currency on Bilateral Trade

\begin{tabular}{|l|l|l|}
\hline \multicolumn{1}{|c|}{ Authors } & \multicolumn{1}{|c|}{$\begin{array}{c}\text { Period under } \\
\text { research }\end{array}$} & \multicolumn{1}{|c|}{$\begin{array}{c}\text { Effect of common cur- } \\
\text { rency/euro on bilateral trade }\end{array}$} \\
\hline Rose, Wincoop (2001) & $1970-1995$ & $58 \%$ \\
\hline Bun, Klaassen (2002) & $1965-2001$ & $3.9-9.6 \% ; 37.8 \%$ \\
\hline Glick, Rose (2002) & $1948-1997$ & $90 \%$ \\
\hline Bun, Klaassen (2007) & $1967-2002$ & $3 \%$ \\
\hline De Nardis, Vicarelli (2003) & $1980-2000$ & $8.9-9.7 \%$ \\
\hline Flam, Nordström (2003) & $1989-2002$ & $15 \%$ \\
\hline Flam, Nordström (2007) & $1995-2005$ & $26 \%$ \\
\hline Micco, Stein, Ordoñez (2003) & $1992-2002$ & $4-16 \%$ \\
\hline Baldwin, Skudelny, Taglioni (2005) & $1991-2002$ & $70-112 \%$ \\
\hline Berger, Nitsch (2008) & $1948-2003$ & about 15\% \\
\hline Maliszewska (2004) & $1992-2002$ & $26.5 \%$ \\
\hline Brouwer, Paap, Viaene (2007) & $1990-2004$ & $7 \%$ \\
\hline Pareja, Vivero, Serrano (2008) & $1950-2004$ & $38-71 \%$ \\
\hline Camarero, Gomez, Tamarit (2013) & $1967-2008$ & $13-16 \%$ \\
\hline Sadeh (2014) & $1991-2011$ & $84-107 \%$ \\
\hline Glick, Rose (2016) & $1948-2013$ & $50 \%$ \\
\hline Source: Own study, & & \\
\hline
\end{tabular}

Source: own study.

Flam and Nordström (2003) found that introduction of the euro earlier than in 2002 contributed to an increase in the overall volumes of trade among the Eurozone member countries by $15 \%$, while the volumes of trade with non-Eurozone countries grew by $8 \%$. Later research disclosed that the common currency increased the Eurozone's domestic trade by $26 \%$ over the period 2002-2005 in comparison to the period 1995-1998, while the volumes of trade with non-Eurozone countries increased by $12 \%$ (Flam \& Nordström, 2007).

One of the most comprehensive studies on the impact of the euro on the volumes of trade was conducted by Micco, Stein and Ordoñez (2003) who employed several gravity models on trade under different conditions. Using the data of 22 countries (including 11 countries of the Eurozone), the authors estimated that the volumes of bilateral trade between the countries of the Eurozone grew by nearly $4 \%-10 \%$ in comparison to the volumes of bilateral trade between non-Eurozone countries; the overall growth of the volumes of trade among the countries of the Eurozone constituted nearly $9 \%-16 \%$ in comparison to the overall growth of the volumes of trade among non-Eurozone countries.

Baldwin, Skudelny and Taglioni (2005) proved that elimination of relatively insignificant trade barriers might have an extremely significant impact on the volumes of trade. The results of their research revealed that only the establishment of the EMU increased 
the volumes of the Eurozone's domestic trade by $70 \%-112 \%$ in accordance with the defined terms of the research, while the volumes of trade between third countries and the countries of the Eurozone grew by $27 \%$.

By employing the data of 22 industrial countries for 1948-2003, Berger and Nitsch (2008) found that trade intensity among European countries had been gradually increasing even before introduction of the common currency. Nevertheless, the authors also estimate that the volumes of trade between the EMU member countries have increased by about $15 \%$ after the adoption of the euro (while other factors remain constant). Authors argue that '...the finding of a sizable increase in trade after the introduction of the euro are very sensitive to the analyzed time period and the regression specification' (Berger \& Nitsch, 2008, p. 1248).

Maliszewska (2004) researched the flows of trade between the EU member countries and the countries of Central and Eastern Europe. The results of the research revealed that the impact of the euro on the overall volumes of trade amounted to $26.5 \%$. In addition, it was established that the common currency should determine an increase in the volumes of trade in all new Eurozone member countries, especially in the ones (e.g. Poland, Latvia, Lithuania) which have not yet reached the level of trade integration typical of the EU oldtimers. Using the data of 29 countries (including $25 \mathrm{EU}$ member countries) for the period 1990-2004, Brouwer, Paap and Viaene (2007) estimated that the impact of the EMU on the direct exports of the Union members accounted for nearly $7 \%$. However, the authors noted that the impact of the euro on the volumes of trade in each of the countries might vary from $0.84 \%$ in Lithuania to $13.3 \%$ in Malta.

Pareja, Vivero and Serrano (2008) analysed the impact of monetary unions on the intensity of trade flows. By employing the gravity model of trade and the data of 25 countries for the period 1950-2004, the authors found that monetary unions promoted domestic trade among the countries-participants, and the impact of the euro on the volumes of the Eurozone's domestic trade grew from $38 \%$ to $71 \%$ over the period under research. It was also established that regional trade unions had an economically significant positive impact on the volumes of domestic trade inside the union: for instance, the volumes of domestic trade grew by $48 \%$ in the EU member countries and by $30 \%$ in EFTA and NAFTA member countries over the period under research.

Camarero, Gomez and Tamarit (2013) analysed the long-run effect of the euro on trade for the twelve initial EMU countries for the period 1967-2008. The results show that the euro has had a positive though small effect on trade, but the effect of the EMU is not equal in all countries. The study accomplished by Sadeh (2014) encompasses 145 countries; however, the research excludes transition economies and includes just 11 euro area member states. This study argues that the euro area more than doubled trade among its members, but this process was delayed and fitful.

Glick and Rose repeated the study in 2016. The authors used a variety of models and a panel of annual data that covers more than 200 countries between 1948 and 2013, including fifteen years of EMU. The authors found that different econometric methodologies deliver different results. At the same time, the authors stated that the most appropriate methodology they used (a panel approach which included country-pair fixed effects on the largest possible span of data across countries and time) indicated that the EMU had boosted exports by around $50 \%$. 
Some scientific articles propose that the new members of the EMU do not obtain such significant trade benefits as the countries that joined the union at the beginning of its formation. Aristovnik and Meze (2010), who researched the trends of trade growth in Slovenia over the period 1996-2006, found that after the establishment of the EMU, Slovenian exports to the countries of the Eurozone increased by $10.6 \%$ in the short run, while the imports from the countries of the Eurozone dropped by $6.6 \%$. However, no positive longterm effects of the EMU on the volumes of Slovenian trade had been observed. Similar results were reported by Cieślik, Michałek and Mycielski (2012) who employed the data of Slovakian and Slovenian trade for 1992-2009 and estimated that neither the membership in the EMU nor adoption of the euro contributed to an increase in the exports of the countries under research. Based on the research results, the authors state that introduction of the euro in the future should not significantly contribute to the development of trade in other new EU member countries from Central and Eastern Europe. Jagelka (2013) investigated four new member states of the EMU (Slovakia, Slovenia, Malta and Cyprus) and concluded that their trade with other countries of the euro area had risen by $9 \%$.

On balance, the analysis of the scientific literature on plausible impact of a common currency on international trade (considering the case of the EMU in particular) proposes that scientific studies report rather different results concerning the impact of the euro on the volumes of the Eurozone's domestic trade and the impact of the common currency on the volumes of trade between the members of the monetary union and third countries. The differences in the results might have been determined by dissimilar periods under research, the variety of groups of countries and the differences in the statistical methods employed. In addition, previous studies reveal that the impact of the euro on the volumes of trade in the new EMU member countries may also differ from that in the old-timers; in some cases, the results may vary for short- and long-term research because trade gains its highest intensity only in the long run after introduction of a common currency.

\section{MATERIAL AND METHODS}

Based on the analysis of previous research, the hypothesis that the euro adoption has a positive and significant impact on the trade volumes of Lithuania is tested. Previous empirical research on international trade was mostly based on the gravity model of trade. The classical gravity model enables to assess bilateral trade between the countries, when trade depends on the size of trade partners' economies (commonly measured in GDP) and distance between the countries. According to Micco, Stein and Ordoñez (2003) and Flam (2009), the gravity model of trade is one of the most successful methods developed for the empirical research of international trade as well as for explanation of the flows of bilateral trade between countries. The variables of the model in economic research are commonly presented as logarithms, and a double logarithm (log-log) regression model has been developed (Rose, 2000; Bun \& Klaassen, 2007):

$$
\ln \left(F_{i j t}\right)=\beta_{0}+\beta_{1} \ln \left(M_{i t}\right)+\beta_{2} \ln \left(M_{j t}\right)+\beta_{3} \ln \left(D_{i j}\right)+\varepsilon_{i j t}
$$

where:

$F_{i j t}$ - volumes of trade between countries $i$ and $j$ at time moment $t$;

$M_{i t}, M_{j t}$ - size of economy (GDP) in countries $i$ and $j$, respectively, at time moment $t$;

$D_{i j}$ - distance between countries $i$ and $j$; 
$\beta_{0}, \beta_{1}, \beta_{2}, \beta_{3}$ - coefficients of the model;

$\varepsilon_{i j t}$ - random errors.

Coefficients of the variables in the model show elasticity of trade in respect of the determinants that are incorporated, i.e. the model reveals a one-percent change in trade when the values of GDP or distance between the countries vary.

In some empirical studies, authors additionally incorporate other types of variables that may have the impact on the flows of trade between the countries under research, for instance, GDP per capita, exchange rates or their fluctuations, rates of economic growth etc. What is more, with a view to assessing the impact of additional variables on the flows of trade, the gravity model can be complemented with dummy variables, which reveal the significance of the common language and border (in the case of regional trade unions) as well as influence of the common currency and other determinants on bilateral trade (Rose, 2000; Micco, Stein, \& Ordoñez, 2003; Flam \& Nordström, 2003; Bun \& Klaassen, 2007).

Hence, with reference to the analysis of previous empirical studies, the gravity model of trade is employed to assess the impact of the euro on trade volumes between Lithuania and other countries (Formula 2). It incorporates standard variables, i.e. GDP and distance between trading countries, and a dummy variable, i.e. the euro.

$$
\begin{aligned}
& \ln \left(T R A D E_{L T j t}\right)=\beta_{0}+\beta_{1} \ln \left(G D P_{L T t}\right)+\beta_{2} \ln \left(G D P_{j t}\right)+ \\
& +\beta_{3} \ln \left(D I S T A N C E_{L T j}\right)+\beta_{4} E U R_{L T j t}+\varepsilon
\end{aligned}
$$

where:

$T R A D E_{L T j t}$ - value of trade (sum of exports and imports) between Lithuania (LT) and a foreign country $j$ at time moment $t$;

$G D P_{L T t}$ - Lithuanian GDP at time moment $t$;

$G D P_{j t}$ - GDP of a foreign country $j$ at time moment $t$;

$D I S T A N C E_{L T j}$ - distance between Lithuania and a foreign country j;

$E U R_{L T j t}$ - dummy variable that gains value 1 if Lithuania and a foreign country $j$ have the same currency, i.e. the euro at time moment $t$, and value 0 otherwise.

The coefficient $\beta_{4}$ reveals the impact of the euro adoption on the Lithuanian trade. Since dependent variable TRADE is expressed as a logarithm, the variation of trade induced by having common currency $\left(E U R_{L T j t}=1\right)$ with respect to the case of not having common currency $\left(E U R_{L T j t}=0\right)$ is given by

$$
\left(e^{\beta_{4} \cdot 1} / e^{\beta_{4} \cdot 0}-1\right) \cdot 100 \%=\left(e^{\beta_{4}}-1\right) \cdot 100 \%
$$

The analysis includes 40 foreign countries (trade partners) and estimation of the model is carried out on data for the period 2002-2016. The research covers the annual volumes of the Lithuanian trade (exports and imports of goods) with 40 main trade partners that accounts for nearly $95 \%$ of the total volume of the Lithuanian international trade. The countries under investigation are $27 \mathrm{EU}$ member countries (17 members of the Eurozone) and 13 other countries, i.e. China, Canada, USA, Russia, Belarus, India, Japan, Kazakhstan, Norway, South Korea, Turkey, Ukraine and Switzerland.

The data on exports and imports of the countries were extracted from the United Nations (UN) Comtrade Database, and the data of GDP were obtained from the National Accounts Main Aggregates Database. The values of exports, imports and GDP are expressed 
in US dollars; the distance between the countries is measured as a distance between the capitals in kilometres, based on World Distance Calculator. The statistical analysis of the data is performed and the gravity model is estimated using software EViews.

\section{RESULTS AND DISCUSSION}

The gravity model of trade, presented by equation (2), is employed to assess the impact of the euro adoption on the Lithuanian international trade. Descriptive statistics of the analysed variables is presented in Table 2. The largest trade partners of Lithuania are Russia, Germany and Poland, meanwhile the least trade volumes are observed with small countries such as Malta, Cyprus and Luxembourg.

Table 2. Descriptive Statistics of the Variables

\begin{tabular}{|l|r|r|r|r|}
\hline \multicolumn{1}{|c|}{ Statistics } & $\begin{array}{c}\text { TRADE } \\
\text { USD }\end{array}$ & $\begin{array}{c}\text { GDP } \text {, } \\
\text { prillion, at current }\end{array}$ & $\begin{array}{c}\text { GDP, allion USD } \\
\text { prices, billion USD }\end{array}$ & DISTANCE \\
\hline Mean & 1.0414 & 35.9938 & 1223.087 & 2148.675 \\
\hline Median & 0.3741 & 39.7316 & 303.1172 & 1391.905 \\
\hline Maximum & 16.2513 & 48.5572 & 18624.48 & 8185.700 \\
\hline Minimum & 0.0024 & 14.2754 & 4.4671 & 171.7300 \\
\hline Standard deviation & 1.8888 & 10.5965 & 2639.758 & 2117.125 \\
\hline Observations & 600 & 600 & 600 & 600 \\
\hline
\end{tabular}

Source: own study.

Table 3 presents correlation coefficients between variables. As none of the variable is distributed by normal distribution because of strong outlier effect (great differences among countries) Spearman rank-order correlation coefficient is used. Trade significantly correlates with distance, Lithuanian GDP and GDP of foreign countries, but this relation is not strong.

Table 3. Correlation Analysis

\begin{tabular}{|l|c|c|c|c|c|}
\hline \multicolumn{1}{|c|}{ Correlation Probability } & TRADE $_{\text {LT }}$ & GDP $_{\text {LT }}$ & GDP & DISTANCE & EUR \\
\hline \multirow{2}{*}{ TRADE $_{\text {LT }}$} & $\begin{array}{c}1.0000 \\
-\end{array}$ & & & & \\
\hline \multirow{2}{*}{ GDP $_{\text {LT }}$} & 0.2343 & 1.0000 & & & \\
\hline \multirow{2}{*}{ GDP } & 0.0000 & - & & & \\
\hline \multirow{2}{*}{ DISTANCE } & 0.3938 & 0.1381 & 1.0000 & & \\
& 0.0000 & 0.0007 & - & & \\
\hline \multirow{2}{*}{ EUR } & -0.4780 & 0.0000 & 0.4167 & 1.0000 & \\
& 0.0000 & 1.0000 & 0.0000 & - & \\
\hline
\end{tabular}

Source: own study.

All correlation coefficients between trade and other indicators are positive except distance, which means that trade volumes are higher with large, adjacent economies and countries with the same currency (EUR). Correlation coefficients between independent variables are also quite low, so multicollinearity problem does not exist. The panel least 
squares method is used to estimate the parameters of the model. Estimates of parameters and other characteristics of the model are presented in Table 4.

Table 4. Results of the Gravity Model of Trade

\begin{tabular}{|l|r|r|}
\hline \multicolumn{1}{|c|}{ Variable } & Coefficient & \multicolumn{1}{c|}{ Prob. } \\
\hline C & -1.4885 & 0.5619 \\
$\ln ($ GDP $L$ T) & 0.4676 & 0.0000 \\
$\ln$ (GDP) & 0.8031 & 0.0000 \\
In(DISTANCE) & -1.5807 & 0.0000 \\
EUR & 0.3631 & 0.0235 \\
\hline Adj-R2 & 0.7088 & \\
Prob(F-statistic) & 0.0000 & \\
\hline
\end{tabular}

Source: own study.

All parameters are significant at the significance level of 0.05 , and the adjusted coefficient of determination amounts to 0.7088 , which proposes that independent variables in the regression model explain variations of the dependent variable (i.e. the Lithuanian international trade) by $70.88 \%$. One-percent increase in the value of GDP of a foreign country determines an increase in the Lithuanian international trade by $0.80 \%$; one-percent increase in Lithuanian GDP determines an increase in the Lithuanian international trade by $0.47 \%$.

The analysis of the dummy variables proposes that the euro has a positive impact on the volumes of the Lithuanian international trade. The impact of the euro on the Lithuanian international trade is estimated by formula (3):

$$
\left(e^{0.3631}-1\right) \cdot 100 \%=0.4378 \cdot 100 \%=43.78 \%
$$

Hence, the impact of the euro adoption on the Lithuanian international trade accounts for about $44 \%$, while the other conditions remain stable. Comparing these results with the ones obtained in previous scientific studies, it can be stated that similar results were reported by Pareja, Vivero and Serrano (2008), Glick and Rose (2016), who established that the impact of the euro introduction on international trade makes up 50\%.

The analysis of effects shows that random cross-sections and time effects are significant. The Hausman test accepts the null hypothesis that there is no misspecification see (Table 5). So, the errors are not correlated with the regressors.

Table 5. Hausman Test

\begin{tabular}{|l|r|c|c|}
\hline \multicolumn{1}{|c|}{ Test Summary } & Chi-Sq. Statistic & Chi-Sq. d.f. & Prob. \\
\hline Cross-section random & 1.5436 & 3 & 0.6722 \\
Period random & 0.0000 & 3 & 1.0000 \\
Cross-section and period random & 5.1302 & 2 & 0.0769 \\
\hline
\end{tabular}

Correlated Random Effects - Hausman Test; Test cross-section and period random effects. Source: own study.

However, effects do not improve the model as its precision is even lower comparing with the model without effects (Table 6). The results of panel regression with random cross-sections and time effects show that effect of the euro is lower, i.e. $23.32 \%$. Similar results were reported by Maliszewska (2004), Flam and Nordström (2007) (Table 1). 
Table 6. Panel Regression

\begin{tabular}{|c|c|c|c|c|}
\hline Variable & Coefficient & Std. Error & t-Statistic & Prob. \\
\hline C & -1.8315 & 2.2163 & -0.8263 & 0.4089 \\
\hline $\ln \left(G D P_{L T}\right)$ & 0.5397 & 0.0939 & 5.7493 & 0.0000 \\
\hline $\ln (G D P)$ & 0.7303 & 0.0648 & 11.2622 & 0.0000 \\
\hline In(DISTANCE) & -1.5079 & 0.1685 & -8.9480 & 0.0000 \\
\hline EUR & 0.2096 & 0.0833 & 2.5161 & 0.0121 \\
\hline \multicolumn{3}{|c|}{ Effects Specification } & S.D. & Rho \\
\hline \multicolumn{3}{|l|}{ Cross-section random } & 0.8582 & 0.8270 \\
\hline \multicolumn{3}{|l|}{ Period random } & 0.0904 & 0.0092 \\
\hline \multicolumn{3}{|l|}{ Idiosyncratic random } & 0.3820 & 0.1638 \\
\hline \multicolumn{5}{|c|}{ Weighted Statistics } \\
\hline R-squared & 0.3789 & \multicolumn{2}{|l|}{ F-statistic } & 90.7279 \\
\hline Adjusted R-squared & 0.3747 & \multicolumn{2}{|l|}{ Prob(F-statistic) } & 0.0000 \\
\hline Sum squared resid & 86.9089 & \multicolumn{2}{|c|}{ Durbin-Watson stat } & 0.8721 \\
\hline \multicolumn{5}{|c|}{ Unweighted Statistics } \\
\hline R-squared & 0.7064 & \multirow{2}{*}{\multicolumn{2}{|c|}{ Durbin-Watson stat }} & \multirow{2}{*}{0.1611} \\
\hline Sum squared resid & 506.5064 & & & \\
\hline
\end{tabular}

Dependent variable: In( ); Method: Panel EGLS (Two-way random effects); Sample: 2002-2016.

Source: own study.

Since the current research covers only the two-year period after the adoption of the euro in Lithuania, it should be noted that the results of the estimations do not reflect a plausible long-term impact of the common currency on the Lithuanian international trade. In the long term, the country's international trade can be affected by a variety of economic and political factors. In comparison to 2014, the Lithuanian international trade in 2015 decreased due to significantly lower volumes of trade with the Commonwealth of Independent States (CIS), for instance, Russia, Belarus and Kazakhstan. The results of the research show that the share of the Lithuanian trade of goods with the countries of the Eurozone compared with the entire volume of trade grew from $39.0 \%$ to $42.2 \%$ (i.e. by 3.2 percentage points) in 2015, while the share of the Lithuanian trade with the rest of the EU member countries grew by 1.9 percentage points (Figure 1).

Summarising the results of the empirical research, it can be concluded that the adoption of the euro in Lithuania has a positive impact on the country's trade volume.

\section{CONCLUSIONS}

The analysis of the Lithuanian international trade before and after introduction of the euro revealed that the common currency had a positive impact on the changes of trade. The impact of the euro adoption on the Lithuanian international trade, assessed employing the gravity model, amounts to $23-44 \%$ and depends on the model used, i.e. whether random cross-sections and time effects are included or not. Comparing the results of the estimations with the ones obtained in previous scientific studies, it was observed that similar results were reported by Maliszewska (2004), Flam and Nordström (2007), Pareja, Vivero and Serrano (2008), Glick and Rose (2016). On balance, it can be stated that the adoption of the common currency contributed to an increase in the Lithuanian trade with the main partners. 


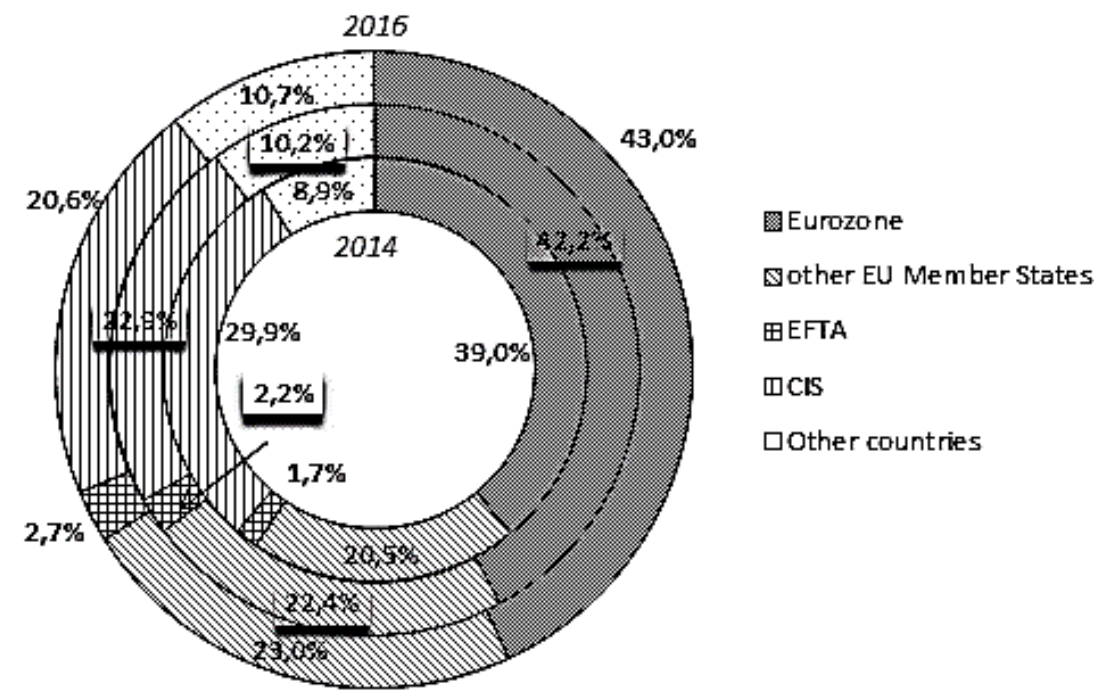

Figure 1. The structure of the Lithuanian trade of goods by trade partners Source: compiled by the authors with reference to the data of UN Comtrade.

Berger and Nitsch (2008) discuss the importance of monetary integration achieved before the adoption of the euro to the development of trade among the Eurozone countries. Lithuania has been participating in the Exchange Rate Mechanism II (ERM II) since the middle of 2004. It was one of the first new EU Member States to join ERM II and it unilaterally committed to maintaining a fixed exchange rate regime (3.4528 litas per 1 euro). A relatively large impact of the euro introduction in Lithuania on trade with the euro area countries can also be influenced by the country's long stay in ERM II.

Studies of other researchers showed that different impacts of the common currency on trade volumes and results depend on many factors, i.e. country, period, method and so on. This research supplements previous studies and reveals that the euro adoption has a positive impact on specifically Lithuanian trade volumes. The results can be used to discuss the positive impact of the common currency on a country's economy. It is important for those EU members which still have not adopted the euro.

Since this research covers only a two-year period after adoption of the euro in Lithuania, it should be noted that the results of the estimations do not reflect a long-term impact of the common currency on the Lithuanian international trade. As a consequence, the study should be repeated in several years to refine the results.

\section{REFERENCES}

Alesina, A., Barro, R.J., \& Tenreyro, S. (2002). Optimal currency areas. NBER Macroeconomics Annual 2002, 17, 301-356.

Aristovnik, A., \& Meze, M. (2010). The economic and monetary union's effect on (international) trade: the case of Slovenia before euro adoption. Michigan: William Davidson Institute Working Papers Series wp982, William Davidson Institute at the University of Michigan. 
Baldwin, R., Skudelny, F., \& Taglioni, D. (2005). Trade effects of the euro: evidence from sectoral data. European Central Bank, Working Paper Series No. 446/February 2005. Retrieved on January 17, 2018 from https://www.ecb.europa.eu/pub/pdf/scpwps/ecbwp446.pdf?36889cb1fe38a1fb76340b6be25a42f1

Bayoumi, T., \& Eichengreen, B. (1997). Ever closer to heaven? An optimum-currency-area index for European countries. European Economic Review, 41(3-5), 761-770. https://doi.org/ 10.1016/S0014-2921(97)00035-4

Berger, H., \& Nitsch, V. (2008). Zooming out: the trade effect of the euro in historical perspective. Journal of International Money and Finance, 27(8), 1244-1260.

Bitans, M., \& Kaužens, E. (2004). Impact of the euro adoption on the economy of Latvia. Bank of Latvia, Working Paper 2/2004. Retrieved on January 17, 2018 from https://www.bank.lv/public_files/images/img_lb/izdevumi/english/citas/Impact_of_the_Euro_Adoption.pdf

Borowski, J., Brzoza-Brzezina, M., Czogała, A., Fic, T., Kot, A., Jędrzejowicz, T., Mroczek, W., Polański, Z., Rozkrut, M., Rubaszek, M., Sławiński, A., Woreta, R., \& Żółkiewski, Z. (2004). A report on the costs and benefits of Poland's adoption of the euro. National Bank of Poland. Retrieved on January 20, 2018 from https://www.nbp.pl/en/publikacje/e_a/euro_adoption.pdf

Brouwer, J., Paap, R., \& Viaene, J.M. (2007). The trade and FDI effects of EMU enlargement. CESifo Working Paper No. 2123. Category 7: Trade Policy, October 2007. Retrieved on January 17, 2018 from https://www.cesifo-group.de/DocDL/cesifo1_wp2123.pdf

Broz, T. (2005). The theory of optimum currency areas: a literature review. Privredna Kretanja $i$ Ekonomska Politika, 15(104), 52-78.

Bun, M., \& Klaassen, F. (2007). The euro effect on trade is not as large as commonly thought. Oxford Bulletin of Economics and Statistics, 69(4), 473-496.

Bun, M., \& Klaassen, F. (2002). Has the euro increased trade?. Tinbergen Institute Discussion Papers, 108(2). Retrieved on January 25, 2018 from http://papers.tinbergen.nl/02108.pdf

Camarero, M., Gomez, E., \& Tamarit, C. (2013). EMU and trade revisited: long-run evidence using gravity equations. World Economy, 36(9), 1146-1164. https://doi.org/10.1111/twec.12090

Cieślik, A., Michałek, J.J., \& Mycielski, J. (2012). Euro and trade flows in Central Europe. Equilibrium. Quarterly Journal of Economics and Economic Policy, 7(3), 7-26.

Corden, W.M. (1972). Monetary integration. Essays in International Finance, No. 93, International Finance Section, Princeton University. Retrieved on November 7, 2017 from https://www.princeton.edu/ ies/IES_Essays/E93.pdf

Davulis, G. (2012). European Monetary Union: creation, advantages, today's problems. Societal Innovations for Global Growth, 1(1), 479-496. (in Lithuanian)

De Nardis, S., \& Vicarelli, C. (2003). Currency union and trade: the special case of EMU. Review of World Economics, 139(4), 625-649.

Eurostat database. Retrieved on March 20, 2018 from http://ec.europa.eu/eurostat/data/database

Fidrmuc, J. (2004). The endogeneity of the optimum currency area criteria, intra-industry trade, and EMU enlargement. Contemporary Economic Policy, 22(1), 1-12, https://doi.org/10.1093/cep/byh001

Flam, H., \& Nordström, H. (2003). Trade volume effects of the euro: aggregate and sector estimates. Institute for International Economic Studies, Stockholm University, Seminar Paper No. 746. Retrieved on February 3, 2018 from http://www.diva-portal.org/smash/get/diva2:189451/FULLTEXT01.pdf

Flam, H., \& Nordström, H. (2007). Explaining large euro effects on trade: the extensive margin and vertical specialization. Retrieved February 2, 2018 from http://perseus.iies.su.se/ flam/Version20070827.pdf on 
Flam, H. (2009). The impact of the euro on international trade and investment: a survey of theoretical and empirical evidence. Swedish Institute for European Policy Studies SIEPS, Report No. 8. Retrieved on February 5, 2018 from http://www.sieps.se/en/publications/2009/the-impact-ofthe-euro-on-international-trade-and-investment-20098/Sieps_2009_8.pdf?

Frankel, J.A., \& Rose, A.K. (1998). The endogeneity of the optimum currency area criteria. Economic Journal, 108(449), 1009-25.

Glick, R., \& Rose, A.K. (2002). Does a currency union affect trade? The time-series evidence. European Economic Review, 46(6), 1125-1151.

Glick, R., \& Rose, A.K. (2016). Currency unions and trade: a post-EMU reassessment. European Economic Review, 87, 78-91. https://doi.org/10.1016/j.euroecorev.2016.03.010

Horváth, R., \& Komárek, L. (2002). Optimum currency area theory: a framework for discussion about monetary integration. Warwick Economic Research Papers, No. 647. Retrieved on November 10, 2017 from http://www2.warwick.ac.uk/fac/soc/economics/research/workingpapers/2008/twerp647.pdf

Ingram, J.C. (1973). The case for European monetary integration. Essays in International Finance, No. 98, International Finance Section, Princeton University. Retrieved on November 15, 2017 from https://www.princeton.edu/ ies/IES_Essays/E98.pdf

Ishiyama, Y. (1975). The theory of optimum currency areas: a survey. IMF Economic Review, 22(2), 344-383.

Jagelka, T. (2013). Bilateral trade and the Eurozone: evidence from new member countries. World Economy, 36(1), 48-63. https://doi.org/10.1111/twec.12013

Kenen, P.B. (1969). The theory of optimum currency areas: an eclectic view. In R.A. Mundell \& A.K. Swoboda (Eds.), Monetary Problems of the International Economy (pp. 41-60), Chicago: The University of Chicago Press.

Kropas, S., \& Kropienè, R. (2005). European money. Vilnius: Lietuvos bankas (in Lithuanian).

Kuodis, R. (2005). Euro introduction in Lithuania: for and against. Pinigy studijos, 2005(4), 89-96. (in Lithuanian)

Levišauskaitè, K., \& Samys, E. (2012). Monetary union's impact on economy of euro zone countries. Taikomoji ekonomika: sisteminiai tyrimai, 6(2), 29-48. (in Lithuanian)

Maliszewska, M. (2004). New member states' trading potential following EMU accession: a gravity approach. Center for Social and Economic Research, Studies \& Analyses No. 286. Retrieved on January 15, 2018 from http://www.case-research.eu/upload/publikacja_plik/3565756_286ok2.pdf

McKinnon, R.I. (1963). Optimum currency areas. The American Economic Review, 53(4), 717-725.

Micco, A., Stein, E., \& Ordoñez, G. (2003). The currency union effect on trade: early evidence from EMU. Economic Policy, 18(10), 315-35.

Mongelli, F.P. (2008). European economic and monetary integration and the optimum currency area theory. European Economy, Economic Papers 302. Retrieved on February 10, 2018 from http://ec.europa.eu/economy_finance/publications/publication12081_en.pdf

Mundell, R.A. (1961). A theory of optimum currency areas. The American Economic Review, 51(4), 657-665.

Pareja, S., Vivero, R., \& Serrano, J.A. (2008). Trade effects of monetary agreements: evidence for OECD countries. European Economic Review, 52(4), 733-755. https://doi.org/10.1016/j.euroecorev.2007.04.002 
Rose, A.K., \& Wincoop, E. (2001). National money as a barrier to international trade: the real case for currency union. American Economic Review, 91(2), 386-390. https://doi.org/10.1257/aer.91.2.386

Rose, A.K. (2000). One money, one market: estimating the effect of common currencies on trade. Economic Policy, 15(30), 08-45. https://doi.org/10.1111/1468-0327.00056

Sadeh, T. (2014). The euro's effect on trade. European Union Politics, 15(2), 215-234, https://doi.org/10.1177/1465116513517013

Silva, S., \& Tenreyro, S. (2010). Currency unions in prospect and retrospect. The Annual Review of Economics, 2, 51-74. https://doi.org/10.1146/annurev.economics.102308.124508

Svrtinov, V.G., Trajkovska, O.G., \& Temjanovski, R. (2014). Cost and benefits of adopting euro. Applied Sciences and Business Economics Journal, 1(3), 57-64.

Šuster, M., Árendáš, M., Benčík, M., Gertler, P., Hajnovič, F., Komínková, Z., Lalinský, T., Nemec, M., Preisinger, D., Solanič, V., Strachotová, A., Tirpák, M., Tőzsér, T., \& Zeman, J. (2006). The effects of euro adoption on the Slovak economy. National Bank of Slovakia. Retrieved on February 10, 2018 from https://www.nbs.sk/_img/Documents/PUBLIK/06_kol1a.pdf

Tavlas, G.S. (1993). The „new“ theory of optimum currency areas. The World Economy, 16(6), 663685. https://doi.org/10.1111/j.1467-9701.1993.tb00189.x

The Bank of Lithuania. (2013). Impact of the euro adoption on the national economy: an overview of the quantitative assessment. Retrieved on November 15, 2017 from https://old.lb.lt/impact_of_the_euro_adoption_on_the_national_economy_an_overview_of_the_quantitative_assessment_1

United Nations. (2017a). Comtrade database, International Trade Statistics. Retrieved on February 15, 2018 from http://comtrade.un.org/data/

United Nations. (2017b). National Accounts Main Aggregates Database. Retrieved on February 20, 2018 from http://unstats.un.org/unsd/snaama/selbasicFast.asp

World Distance Calculator. Retrieved on February 22, 2018 from https://distancecalculator.globefeed.com/World_Distance_Calculator.asp 


\title{
Authors
}

Contribution share of authors is equal and amounted to $25 \%$ each of them.

\section{Gražina Startienè}

Prof., PhD in Social Sciences (Economics), School of Economics and Business, Kaunas University of Technology. Her research interests include international economics and trade, currency and international settlement.

Correspondence to: Prof. Grazina Startiene, PhD, School of Economics and Business, Kaunas University of Technology, K. Donelaicio str. 73, Kaunas, 44029, Lithuania, e-mail: grazina.startiene@ktu.It

ORCID (1) http://orcid.org/0000-0002-9671-8900

\section{Daiva Dumčiuvienè}

Prof., PhD in Social Sciences (Economics), School of Economics and Business, Kaunas University of Technology. Her research interests include international integration economics, competitiveness economics.

Correspondence to: Prof. Daiva Dumciuviene, PhD, School of Economics and Business, Kaunas University of Technology, K. Donelaicio str. 73, Kaunas, 44029, Lithuania, e-mail: daiva.dumciuviene@ktu.It

ORCID (i) http://orcid.org/0000-0002-3500-3389

\begin{abstract}
Alina Stundžienè
Assoc. Prof., PhD in Social Sciences (Economics), School of Economics and Business, Kaunas University of Technology. Her research interests include economic modelling and forecasting, analysis of business environment, financial analysis and evaluation of the performance of the companies.

Correspondence to: Assoc. Prof. Alina Stundziene, PhD, School of Economics and Business, Kaunas University of Technology, K. Donelaicio str. 73, Kaunas, 44029, Lithuania, e-mail: alina.stundziene@ktu.It

ORCID (1) http://orcid.org/0000-0001-6812-8471
\end{abstract}

\section{Andrius Januškevičius}

Master in Economics, School of Economics and Business, Kaunas University of Technology. His research interests include international economics and trade.

Correspondence to: Andrius Januskevicius, School of Economics and Business, Kaunas University of Technology, K. Donelaicio str. 73, Kaunas, 44029, Lithuania

\section{Copyright and License}

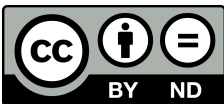

This article is published under the terms of the Creative Commons

Attribution - NoDerivs (CC BY-ND 4.0) License

http://creativecommons.org/licenses/by-nd/4.0/

\section{Published by the Centre for Strategic and International Entrepreneurship - Krakow, Poland}


